\title{
Assessment of Adaptive Capacity of Leaves and Roots of Golf Grass Plant Irrigated by Reclaimed Wastewater
}

\author{
Hind Mouhanni ${ }^{1}$, Brahim Boudinar ${ }^{1} \&$ Abdelaziz Bendou ${ }^{2}$ \\ ${ }^{1}$ Higher Institute of Marine Fisheries, Agadir, Morocco \\ ${ }^{2}$ National School of commerce and management, Agadir, Morocco \\ Correspondence: Hind Mouhanni, National School of commerce and Management, Ibn Zohr University, Agadir, \\ Morocco. Tel: 212-6-6879-7969. E-mail: hmouhanni@yahoo.fr
}

$\begin{aligned} & \text { Received: November 11, } 2013 \quad \text { Accepted: February 10, } 2014 \quad \text { Online Published: August 18, } 2014 \\ & \text { doi:10.5539/ep.v3n4p1 }\end{aligned}$ URL: http://dx.doi.org/10.5539/ep.v3n4p1

The research is financed by National School of commerce and management, Morocco- Agadir

\begin{abstract}
The actual potential of reclaimed wastewater discharged into the bay of Agadir (south Morocco), is 3.65 million $\mathrm{m}^{3} /$ year. This important volume is a significant loss for irrigation in this region characterized by semi-arid climate and a long-suffering of over-exploitation of groundwater. This situation is against to the increasing scarcity of water resources and the quality degradation in the entire region.

The production capacity of M'zar plant available for irrigation purpose without any restrictions (category A of WHO norms), is of about $10000 \mathrm{~m}^{3} /$ day and will reach $50000 \mathrm{~m}^{3} /$ day in the medium term. This production capacity of treated wastewaters will fulfill the whole water needs for irrigation of the entire open spaces of Agadir.

Our study is focused on the assess of adaptive capacity of leaves and roots of golf grass plant irrigated by reclaimed wastewater. It presents the planning, protocol and the results of tests conducted to evaluate the effects of TWW reuse on the growth of leaves and roots of grass plant. The results presented involve monitoring of fresh and dry weight of leaves and roots during the first 41 days of growth of three varieties of golf grass: Penccross (V1), the Ray Gras English (V2) and a mixture of 60\% Ray Gras English and 40\% Red Fescue. The results shown that irrigation with TWW has favored the evolution of the fresh and dry weight of leaves than the root of the grass plant. It's due to nutrients elements content in the TWW and especially nitrogen compared with conventional irrigation with groundwater.
\end{abstract}

Keywords: reclaimed wastewater, irrigation, leaves, roots, weight

\section{Introduction}

Reclaimed wastewater reuse has been a common alternative for irrigation in many countries of the world characterized by an arid climate and a shortage of water resources. Application of reclaimed wastewater reuse for irrigation has been expanded due to the advantage related to the input of nutrients, socio-economic implication, and reduction of the environmental pollution as well as the enhancing of the water resources quality.

In Mediterranean countries, reclaimed wastewater is exponentially used for irrigating ornamental plants in areas with water scarcity. It could be an economic way to decrease pollution of surface waters and provide groundwater recharge for other agricultural fields. A great number of publications have recognized its benefits. In this context, the present research was conducted with the aim of studying the effects of irrigating golf grass with municipal reclaimed water, containing higher concentration of soluble salts than groundwater, on growth of leaves, roots (Hind Mouhanni et al., 2013). Similar results were obtained in the USA by Zalesny and al., in 2008 studied the sodium and chloride accumulation in leaf, woody and root tissues of Populus after irrigation with Landfill leachate and fertilized well water (control). The monitoring started from 2005 to 2006 in Rinelander, Wisconsin. The results have shown that the leachate-irrigated soils at harvest had the greatest $\mathrm{Na}^{+}$and $\mathrm{Cl}^{-}$levels. The soil $\mathrm{Na}^{+}$concentration was nearly 24 times higher than the control. The leachate soil $\mathrm{Cl}^{-}$concentration was three times greater than the control. Across all genotypes, $\mathrm{Na}^{+}$levels were the greatest in the leaves. The same, 
woody sequestered high amounts of $\mathrm{Na}^{+}$and $\mathrm{Cl}^{-}$. As a conclusion, human activities have increased the salts into areas desired for plant growth.

Gregory Evanylo and al., in the USA in 2010 studied reclaimed water for turf grass irrigation. They concluded that the turf grass irrigated by reclaimed wastewater is moderately or highly salt tolerant when fully established. Continuous irrigation with reclaimed water poses a potential soil $\mathrm{Na}$ accumulation problem. Turfgrass assimilate a large amount of N and P with minimal potential losses to groundwater. In Spain, Salgot and al., in 2006 studied wastewater reuse, and they concluded that the reclaimed wastewater can be reused for different applications depending on specific water quality categories. Biological and chemical parameters have to indicate all potential pathogens and chemical intoxications in relation to the origin of sewage. Therefore, it is necessary to find adequate indicators which can be performed by chemical as well as biological quantitative risk assessment.

In Tunisia, Nouha Doudech and al., in 2008 studied the tolerance of turf graminae salinity : Paspalum notatum Flüggé. The main objective of this study is to determine this turfgrass response to salinity. Cuttings of turfgrass were irrigated with water using different concentrations of $\mathrm{NaCl}$. The effect of salinity was assessed on capacity of rooting, chlorophyllian fluorescence and antioxidant enzymes activities such as; catalases (CAT) and the ascorbate dismutase (APX). Results indicated that root and foliar biomass decreased significantly when $\mathrm{NaCl}$ concentration exceeded $8 \mathrm{~g} / \mathrm{l}$. This reduction of biomass is attributed to an alteration of the integrity of photosystem. Moreover, $\mathrm{H}_{2} \mathrm{O}_{2}$ content was found to be positively associated with increased $\mathrm{NaCl}$ concentrations. When $\mathrm{NaCl}$ is below the critical threshold of $8 \mathrm{~g} / \mathrm{l}$, the CAT and APX activities are more ronounced and inhibiting $\mathrm{H}_{2} \mathrm{O}_{2}$ content within the tissue.

Outfits that work brings the impact of treated wastewater reuse for irrigation. It is the origin of salinity and the vulnerability of soils, plants and even groundwater respectively. Our work complete this result by studying the impact of reclaimed wastewater on the growth of different parts of plant which will be compared between two quality of wter in order to control the effect.

In our study, we dealt with the case of Agadir (south of Morocco: altitudes between 30 and $31^{\circ} \mathrm{N}$ ) (Figure 1). The region of Agadir is an agricultural region that is characterized by an arid climate, very limited water resources and poor nutrient soils. The agricultural sector is the largest consumer of water. Thus, the use of treated wastewater in agriculture is a good alternative that will help preserve water resources in the region. Moreover, given the nutritional wealth of the treated wastewater, this solution will permit a recycling of these items and reduce the abusive misuse of fertilizers (Hind Mouhanni et al., 2008; Glueckstern et al., 2008).

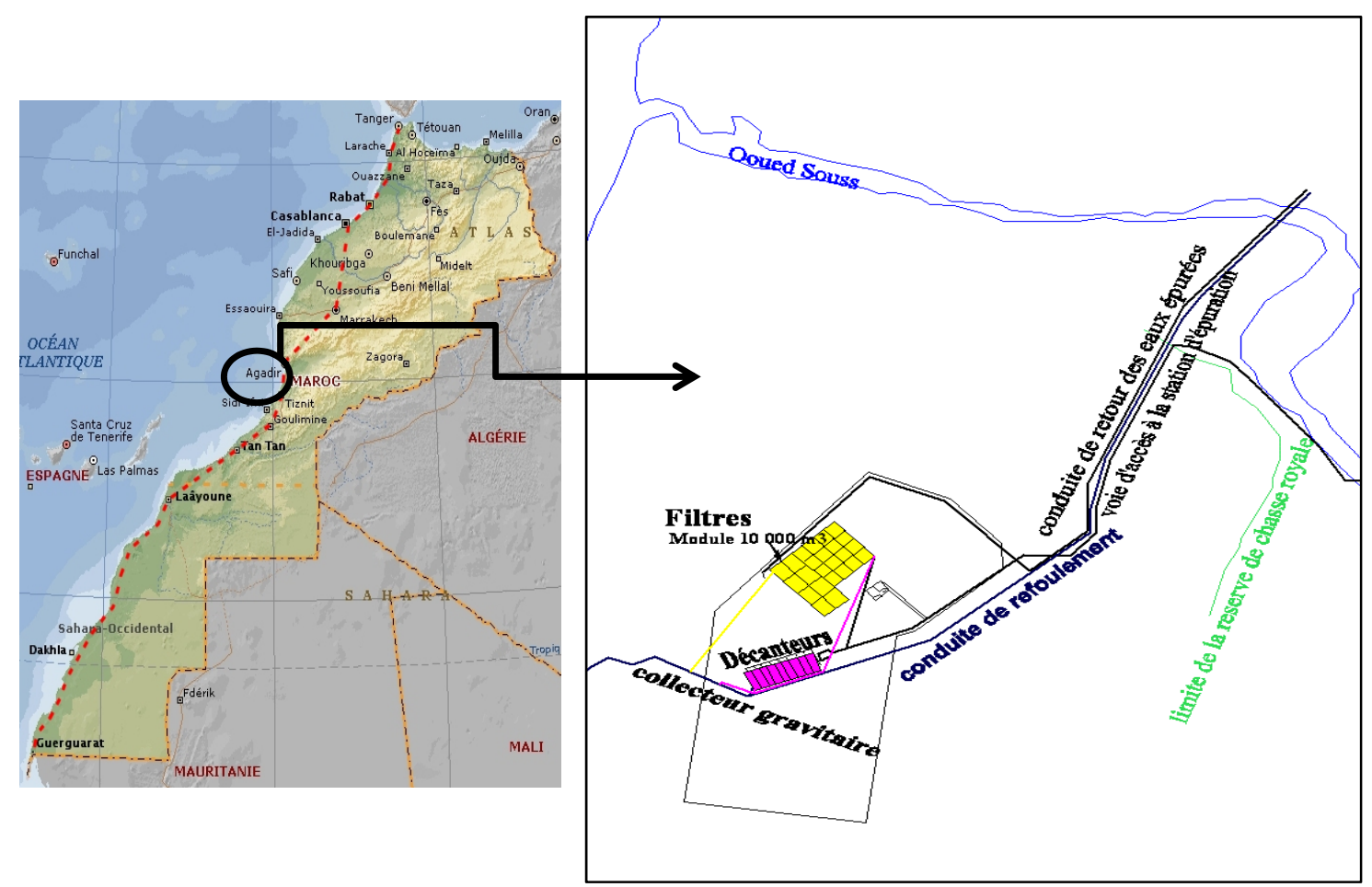

Figure 1. Localization of the M'zar plant of Agadir 
The current potential of wastewater treated by the Agadir M'zar plant, which might be used for unrestricted irrigation (category A WHO standards), is $50,000 \mathrm{~m}^{3} /$ day and will reach $80,000 \mathrm{~m}^{3} /$ day in the medium term. A feasibility study on the reuse of the Agadir M'zar plant wastewater was launched by RAMSA (Régie Autonome Multiservices d'Agadir; Water Supply Service of Agadir). In this context, the total surface of green spaces of Agadir city is estimated to be $878 \times 10^{4} \mathrm{~m}^{2}$ with a need of water for irrigation reaching $8,106 \mathrm{~m}^{3} /$ year. With a daily flow of $50,000 \mathrm{~m}^{3} /$ day, the treated wastewater of the M'zar plant will completely fill this need.

The golf grass alone occupy $30.5 \%\left(268 \times 10^{4} \mathrm{~m}^{2}\right)$ of the total area of green space in Agadir $\left(878 \times 10^{4} \mathrm{~m}^{2}\right)$, with a water consumption estimated to be $3216,103 \mathrm{~m}^{3} /$ year. (Hind mouhanni et al., 2013).

This study focuses on reuse of reclaimed wastewater for golf grass irrigation. It provides the planning, protocol and the results of the tests that are carried out to evaluate the effects of the reuse of reclaimed wastewater for golf grass irrigation. Particular attention is given to the monitoring of the parameters of fresh and dry weight of roots and leaves of grass plant. The monitoring period expands from the first to the $41^{\text {st }}$ day of growth. The results are treated in twenty day periods. It has shown that the reclaimed wastewater embittered the production of the vegetal matter in comparison to the ground water.

\section{Material and Methods}

\subsection{Experimental Site}

The in situ tests are being performed on the site of the wastewater treatment plant of M' zar Ait Melloul where two zones of land have been managed: one for irrigation tests using treated wastewaters issued by of the plant and the other for irrigation tests using the groundwater drawn from a well located in the wastewater treatment plant area.

\subsection{Scheduling of the Tests}

In order to study the impact of reclaimed wastewater reuse on fresh and dry weight of turf grass. We have seeded three varieties of golf courts grass V1 (Penccross), V2 (Ray Gras English) and V3 (Red Fescue and Ray Gras English) on alveolar tray. They are filled with a mixture of the soil ( $75 \%$ topsoil and $25 \%$ sand). Two of them for each variety, as each ras contain 28 alveolar.

The study lasted 41 days since the first day of growth. The seeding of the grains was handmade a grain in each alveolar. The first plants of the lawn germinated after five days of seeding. The intakes of the lawn plant samples are done every twenty days from the first day of germination. In total, the forty one days of growth resulted in three campaigns of sampling. For each campaign 10 samples of the grass plant are harvested (repeated 10 times).

For each plant of the sample, we weigh its fresh weigh (plant, aerial plant, rooted part) and then we dry them in the stove at a temperature of $80^{\circ} \mathrm{C}$ for twenty four hours to make a dry weight. The results include the contribution of the reclaimed wastewater on the root and aerial parts of the grass plant us it reported above.

\section{Results and Discussion}

The plant weight results are reported in curves in order to evaluate the intake of RWW in comparison to the GW. The fresh and dry weight of grass plants leaves and roots are shown in figures 2, 3, 4, 5, 6 and 7 above. 


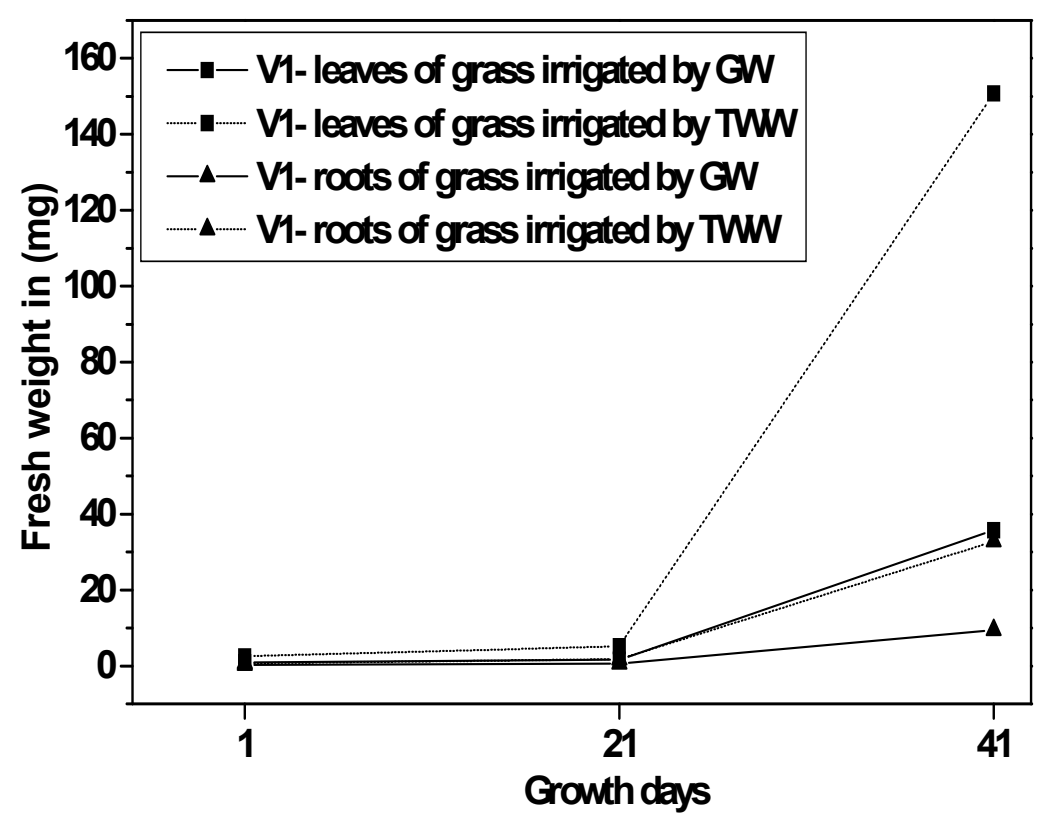

Figure 2. Evolution of the fresh weight of Penccross varietdy (V1)

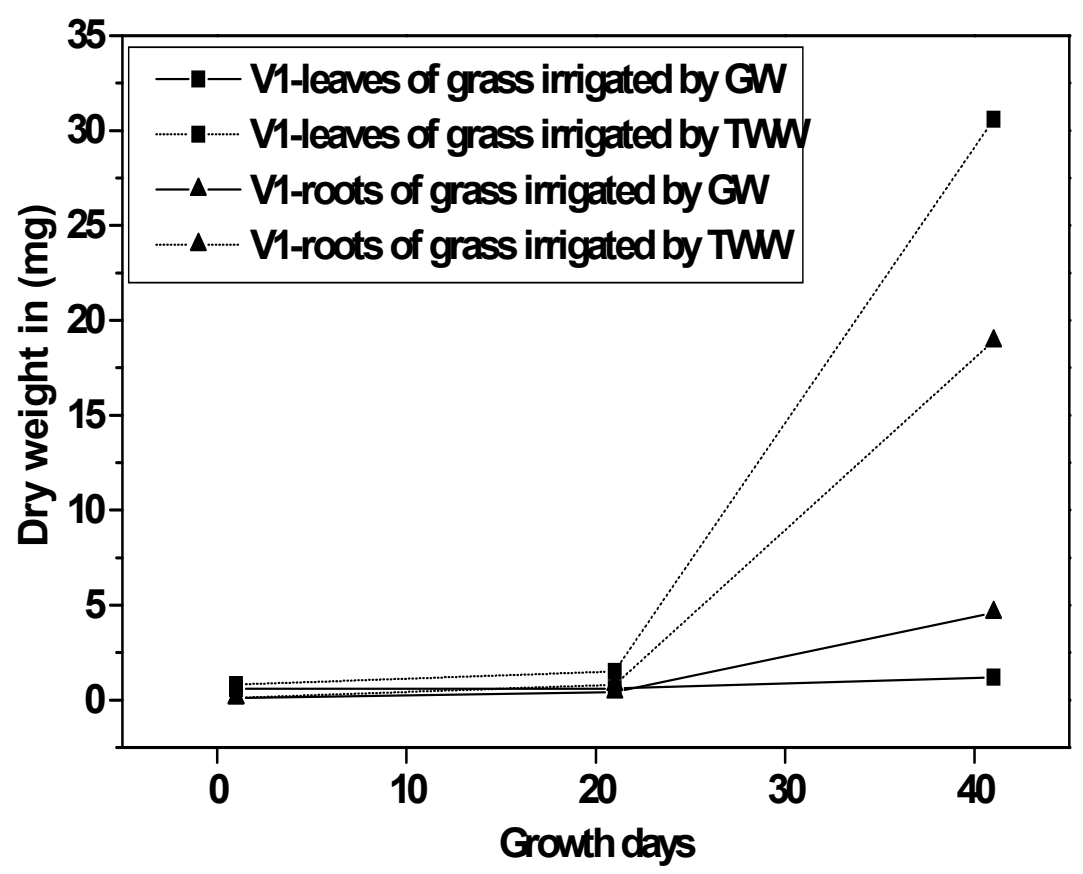

Figure 3. Evolution of the dry weight of Penccross varietdy (V1) 


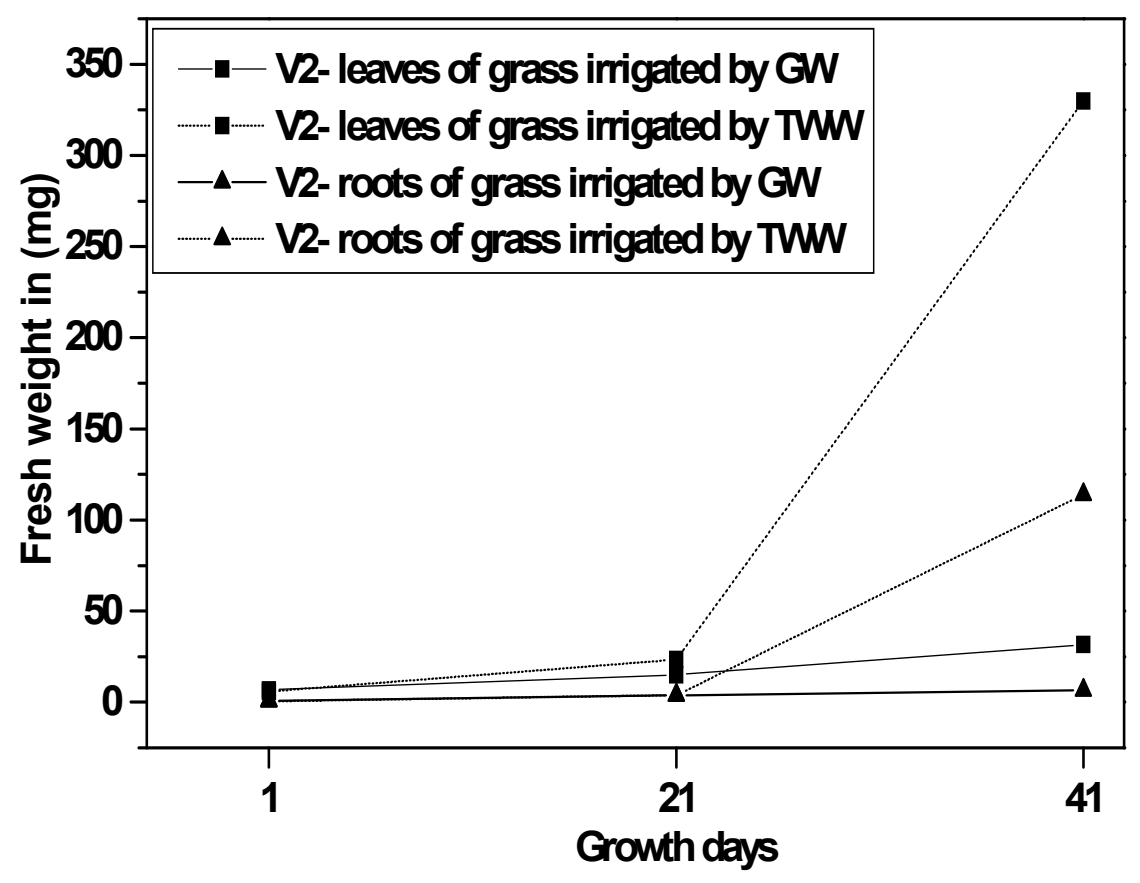

Figure 4. Evolution of the fresh weight of English Ray Gras variety (V2)

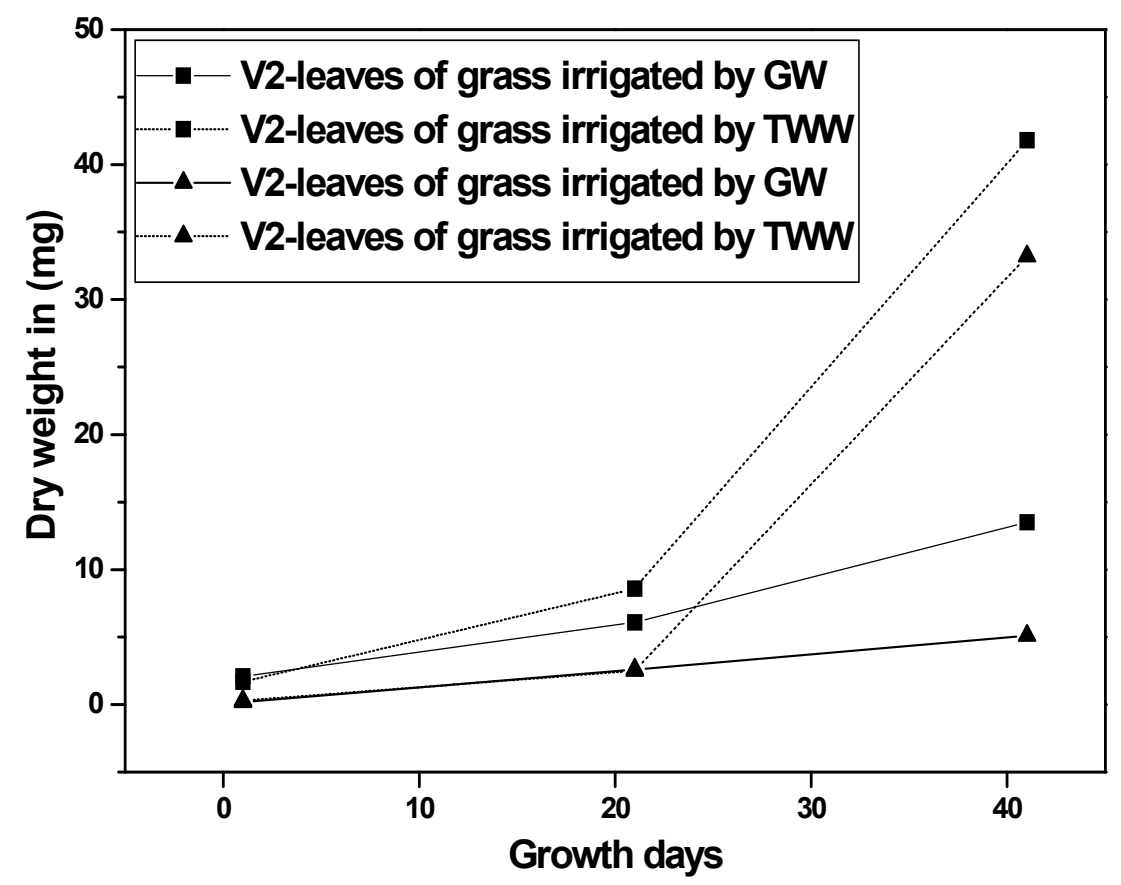

Figure 5. Evolution of the dry weight of English Ray Gras variety (V2) 


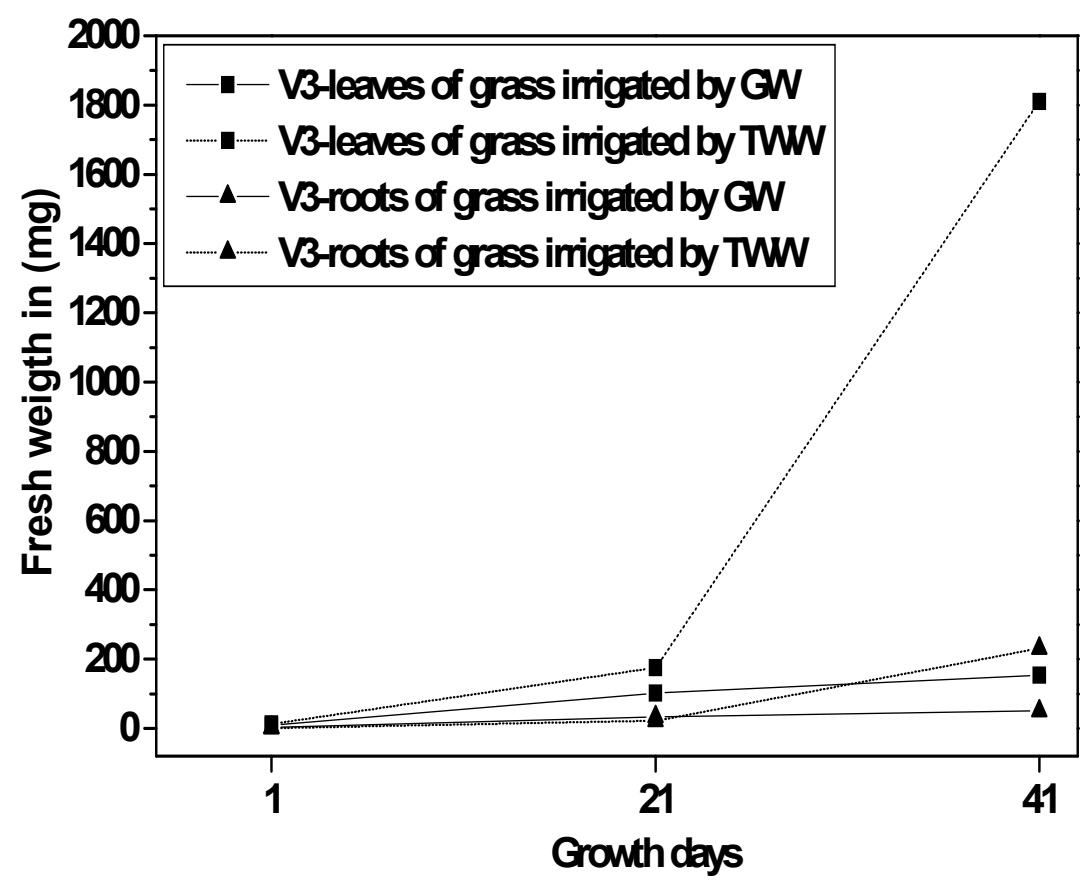

Figure 6. Evolution of the fresh weight of Ray Gras English and Red Fescue variety (V3)

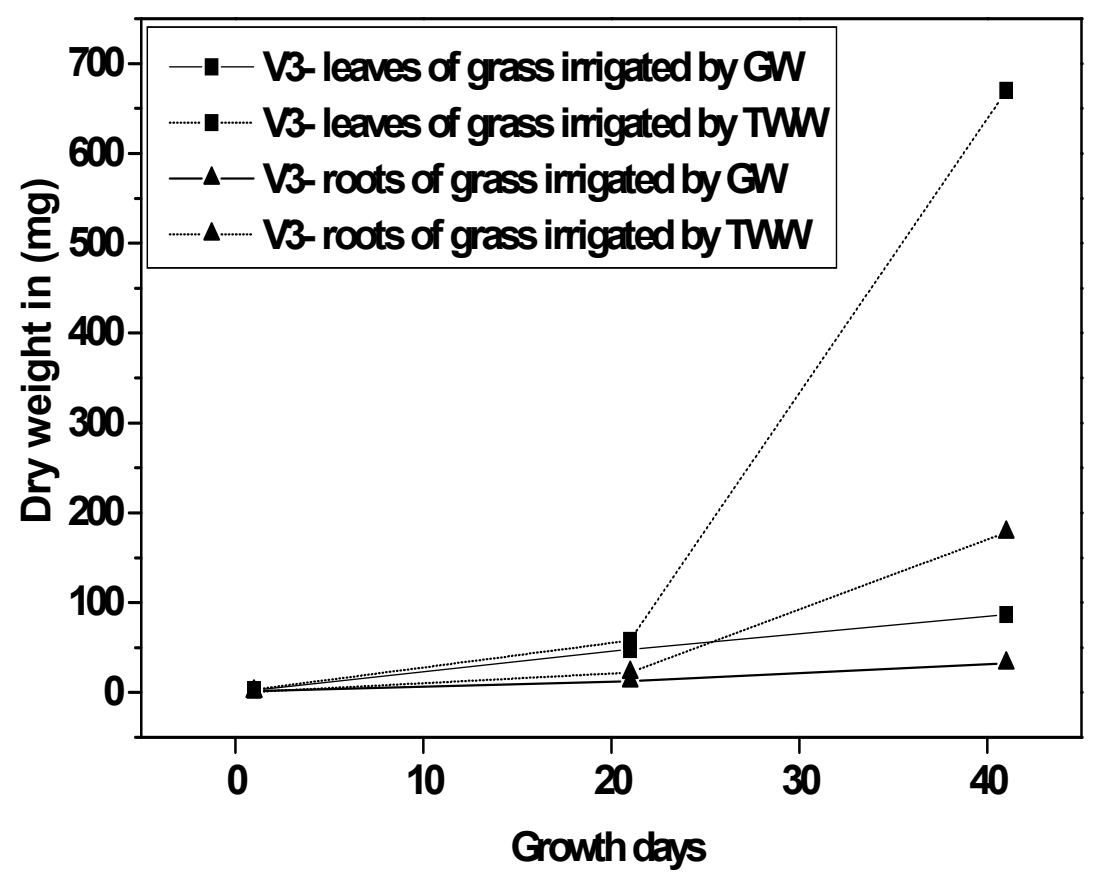

Figure 7. Evolution of the dry weight of Ray Gras English and Red Fescue variety (V3)

The leaves fresh weight of three varieties of golf grass is very important in relation to the roots for both quality of water irrigation RWW and GW. However, in the case of the RWW leaf weight has a better plant growth especially of the aerial part in comparison with the root part. This effect is shown by the length of the leaves that are more advanced and visually as those irrigated by GW. This behavior is more pronounced for the V3 variety which is a mixture of English Ray Gras and Red Fescue. It present a very high fresh and dry weight compared to 
V1 and V2. The water content of plant in the fresh material improves the nutrient intake of each water quality, and involves the adaptive capacity of the golf grass. All varieties irrigated with RWW have a smaller percentage of WC compared to that of GW. This result improve that the RWW irrigation provide an evolution of vegetative growth appeared by the best production of vegetative matter and less water retention unlike irrigation by GW (Mouhanni Hind, 2011, 2008, 2013; Chenini et al., 2002; Eran segala et al., 2010; Yi et al., 2011; Noelia Quevedo, 2012).

Table 1. Comparison of water content relative to the fresh weight of the grass plants in the $41^{\text {st }}$ day for both quality of water irrigation

\begin{tabular}{cccccccc}
\hline & \multicolumn{2}{c}{ GW } & \multirow{2}{*}{ WC * \% } & \multicolumn{2}{c}{ RWW } & \multirow{2}{*}{ WC \% } \\
\cline { 1 - 2 } & fresh weight & dry weight & & fresh weight & dry weight & \\
\hline V1 & 53 & 11 & 79 & 2 & 0,6 & 72 \\
V2 & 120 & 17 & 85 & 18 & 7 & 59 \\
V3 & 666 & 244 & 63 & 88 & 46 & 48 \\
\hline
\end{tabular}

*The water content (WC) is calculated as the ratio of the mass of water contained in the sample and the fresh weight of the sample: FWC $(\%)=($ FM-DM) .100/FM (Hind mouhanni, 2012).

These results are in agreement with those of Zalesny and al., 2007 they studies Sodium and chloride accumulation in leaf, woody, and root tissue of Populus after irrigation with landfill leachate. They concluded that $\mathrm{Na}$ and $\mathrm{CL}$ are greatest in roots and leaves respectively. It's due to the genotype of the plant. It answer the difference between the dry and fresh weight of golf grass leaves and roots for the varieties V1, V2 and V3 which present the. Chartzoulakis and al in Greece 2010, they studied the application of olive mill wastewater (OMW) to a Cretan olive orchard: Effects on soil properties, plant performance and the environment. They applied fresh olive mill wastewater to the soil of an olive orchard for 3 successive years, no negative effects were observed on soil and plants, while the composition of drainage water at a depth of $2 \mathrm{~m}$ was not altered. The results indicated that the controlled application of OMW increased the fertility of the soil, offering the opportunity to recycle the various compounds. Because of the high amounts of organic matter and macronutrients especially potassium, OMW could be considered as a useful, low cost amendment and fertilizer.

Regarding other works like Nguyen Manh Khai and al., 2007, studied Nutrient flows in small-scale peri-urban vegetable farming systems in Southeast Asia-A case study in Hanoi in 2007. They concluded that the reuse of reclaimed wastewater in irrigation contributed to high inputs, and excess use of organic and chemical fertilizers represent a major threat to the soil and water environment. So, the root represents the part most exposed to the stress by the accumulation of nutrient and other chemical element in comparison to the groundwater irrigation with fertilizers. This results explain the V3 variety behaviors which benefit nutritious elements of RWW and present the best adaptive capacity in comparison to V1 and V3.

Table 2. Analysis of major nutrient elements in the grass plant at the end of monitoring

\begin{tabular}{|c|c|c|c|c|c|c|c|}
\hline & $\begin{array}{c}\text { Sampl } \\
\text { es }\end{array}$ & $\begin{array}{c}\text { Total nitrogen } \\
(\%)\end{array}$ & $\begin{array}{l}\text { Standart } \\
\text { deviation }\end{array}$ & $\begin{array}{c}\text { Total phosphorus } \\
(\%) \\
\end{array}$ & $\begin{array}{l}\text { Standart } \\
\text { deviation }\end{array}$ & $\begin{array}{c}\text { Total potassium } \\
(\%) \\
\end{array}$ & $\begin{array}{l}\text { Standart } \\
\text { deviation }\end{array}$ \\
\hline \multirow{3}{*}{ 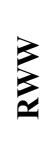 } & V1 & 1,18 & 0,05 & 0,22 & 0 & 1,11 & 0,01 \\
\hline & V2 & 5,38 & 0,19 & 0,62 & 0,02 & 3,95 & 0,04 \\
\hline & V3 & 1,52 & 0,17 & 0,14 & 0 & 1,46 & 0,02 \\
\hline \multirow{3}{*}{ 蛋 } & V1 & $\mathbf{0 , 7}$ & 0,03 & $\mathbf{0 , 0 7}$ & 0 & $\mathbf{0 , 8 8}$ & 0 \\
\hline & V2 & 1,13 & 0,11 & 0,62 & 0,02 & 1,35 & 0,01 \\
\hline & V3 & 2,06 & 0,13 & $\mathbf{0 , 6 3}$ & 0,02 & 2,44 & 0,04 \\
\hline
\end{tabular}


Table 3. Analysis of soil and sand before monitoring

\begin{tabular}{cccccccccc}
\hline \multirow{2}{*}{ Parameters } & \multirow{2}{*}{ Texture } & $\mathbf{p H}$ & $\begin{array}{c}\text { Organic } \\
\text { matter }\end{array}$ & $\begin{array}{c}\text { Total } \\
\text { Nitrogen }\end{array}$ & $\begin{array}{c}\text { Total } \\
\text { limestone }\end{array}$ & $\begin{array}{c}\text { EC 1/5 in } \\
\mathbf{2 0}^{\circ} \mathbf{C}\end{array}$ & $\begin{array}{c}\text { Soluble } \\
\text { salt }\end{array}$ & $\begin{array}{c}\text { P2O5 } \\
\text { ass. }\end{array}$ & $\begin{array}{c}\text { K2O } \\
\text { exch. }\end{array}$ \\
\hline Unit & & & $\%$ & $\%$ & $\%$ & $\mathrm{dS} / \mathrm{m}$ & $\mathrm{g} / \mathrm{kg}$ & $\mathrm{ppm}$ & $\mathrm{ppm}$ \\
Soil & $\mathrm{Ssc}$ & 8,70 & 1,85 & 0,15 & 5,20 & 0,12 & 0,41 & 14,56 & 128,70 \\
Sand & $\mathrm{S}$ & 9,6 & 0,05 & 0,01 & 36,7 & 0,045 & 0,16 & 1 & 24,9 \\
\hline
\end{tabular}

As the previous results prove, Reclaimed wastewater brings nutritious elements like nitrogen, phosphorus and potassium (NPK) indispensable for plant growth. Table 2 show the results content of (NPK) grass plant that involve reclaimed wastewater nutrient intake in comparison to ground water. The added value of soil is not important because it's ranked low in NPK following table 3 data. For the tow quality of water, all varieties present approximately the same rate of NPK, but V3 shows more profit than others. It joined the previous results for dry and fresh weight roots and aerial part Zalesny and al.,2007; Gregory Evanylo and al.,2010.

\subsection{Statistics and Data Analysis}

Statistical analysis was affected by Anova table and Duncan test for dry and fresh weigh plant (aerial and root part) as it shown in the table above.

Table 4. The average dry weight plant of the three varieties studied in relation to two treatments carried out and their classification and grouping of the results of analysis of Duncan's test

\begin{tabular}{ccc}
\hline \multirow{2}{*}{ Variétés } & \multicolumn{2}{c}{ Traitement } \\
\cline { 2 - 3 } & 1 & 2 \\
\hline 1 & $0,002 \mathrm{a}$ & $0,017 \mathrm{a}$ \\
2 & $0,009 \mathrm{a}$ & $0,029 \mathrm{a}$ \\
3 & $0,061 \mathrm{a}$ & $0,31 \mathrm{~b}$ \\
\hline
\end{tabular}

It is noted that the variety 3 ranks first with best results for both treatments produced an average of 0.061 and 0.31 respectively under treatment $n^{\circ} 1$ and treatment $n^{\circ} 2$, followed by the V 2 and finally the V1 with dry weight, respectively 0.009 and 0.002 for treatment $n^{\circ} 1$ and 0.029 and 0.017 for the treatment $n^{\circ} 2$. This result shows the positive evolution of the V3 variety proved in figures 2, 3, 4 for the RWW in relation to V1 and V2 variety.

\section{Conclusion}

The behavior of the three varieties of grass V1 (Penccross), V2 (Ray Grass English) and V3 (Red Fescue and Ray Gras English) irrigated with the two quality of water showed better growth favored by the RWW, It's expressed by:

- The higher dry weight for aerial part related to the root part in comparison to the GW control;

- The mixture variety (V3) present the best adaptive capacity of the RWW;

- More production of vegetal matter than the content water in the leaves and roots.

- Statistical analysis prove a very highly significant difference between the two treatments and the three varieties especially V3 that showed the best results for both treatments

In general, irrigation with RWW in comparison with the water of the water enhances the contribution of fertilizer material especially mineral nitrogen. It promotes the growth of the grass plant in terms of dry weight reflecting vegetable material production. Instead of ground water receive no nutritional intake during the test. Thereafter, we found a fresh weight which more than $50 \%$ of dry weight, it explains the evolution of the fresh weigh whish's a water content but no a vegetal material production.

\section{Acknowledgment}

We present our thanks to the RAMSA ((Régie Autonome Multiservices d'Agadir; Water Supply Service of Agadir) for their collaboration in the course of this work in good conditions at the site of the M'zar plant. We also thank the 
analysis laboratory (water, soil, plant), the regional office of agricultural development in Marrakech which assesses the progress of this work.

\section{References}

Chartzoulakis, K., Psarras, G., Moutsopoulou, M., \& Stefanoudaki, E. (2010). Application of olive mill wastewater to a Cretan olive orchard: Effects on soil properties, plant performance and the environment. Agriculture, Ecosystems and Environment, 138, 293-298. http://dx.doi.org/10.1016/j.agee.2010.05.014

Chenini, F., Trad, M., Rejeb, S., Chaabouni, Z., \& Xanthoulis, D. (2002). Optimization and durability of the treatment and reuse of wastewater in agriculture. Report Ministry of Agriculture, Environment and Water Resources, National Institute for Research in Agricultural Engineering, Forestry, Tunisia.

Doudech, N., Mhamdi, M., Bettaieb, T., \& Denden, M. (2008). Tolérance à la salinité d'une graminée à gazon: Paspalum notatum Flüggé. TROPICULTURA, 26(3), 182-185.

Evanylo, G., Ervin, E., \& Zhang, X. Z. (2010). Reclaimed Water for Turfgrass Irrigation. Water, 2, 685-701. http://dx.doi.org/10.3390/w2030685

Khai, N. M., Ha, P. Q., \& Born, I. O. (2007). Nutrient flows in small-scale peri-urban vegetable farming systems in Southeast Asia-A case study in Hanoi. Agriculture, Ecosystems and Environment, 122, 192-202. http://dx.doi.org/10.1016/j.agee.2007.01.003

Mouhanni, H., Bendou, A., \& Er-Raki, S. (2011). Disinfection of treated wastewater and reuse in irrigation of golf grass: the case of plant M'zar Agadir-Morocco. Water, 3, 1128-1138. http://dx.doi.org/10.3390/w3041128

Mouhanni, H., Bendou, A., \& Mustapha, H. (2013). Study of the Wastewater Purifying Performance in the M'Zar Plant of Agadir, Morocco. Environment and Pollution, 2(3). http://dx.doi.org/10.5539/ep.v2n3p20

Mouhanni, H., Hamdi, H., Bendou A., Cavalli, E., \& Benzine, L. (2012). Impact de la réutilisation des eaux usées épurées en irrigation: analyse ionique des lyxiviats. Revue des Sciences de l'Eau, 25(1), 69-73. http://dx.doi.org/10.7202/1008536ar

Mouhanni, H., Hamdi, H., Bendou, A., Cavalli, E., \& Benzine, L. (2012). Impact de la réutilisation des eaux usées épurées en irrigation: analyse ionique des lyxiviats. Sciences de l'Eau, 25, 69-73. Retrieved from http://id.erudit.org/iderudit/10.7202/1008536ar

Nouha Doudech, M., Mhamdi, T. B., \& Denden, M. (2008). Tolérance à la salinité d'une graminée à gazon: Paspalum notatum Flüggé. Tropicultura, 26(3), 182-185.

Quevedo, N., Sanz, J., Lobo, A., Temprano, J., \& Tejero, I. (2012). Filtration demonstration plant as reverse osmosis pretreatment in an industrial water treatment plant. Desalination, 286, 49-55. http://dx.doi.org/10.1016/j.desal.2011.10.037

Salgot, M. (2008). Water reclamation, recycling and reuse: Implantation issues. Desalination, 218, 190-197. http://dx.doi.org/10.1016/j.desal.2006.09.035

Segala, E., Shouseb, P., Poss, J. A., Crohn, D. M., \& Bradford, S. A. (2010). Recommendations for nutrient management plans in a semi-arid environment. Agriculture, Ecosystems and Environment, 137, 317-328. http://dx.doi.org/10.1016/j.agee.2010.03.002

Yi, L. L., Jiao, W. T., Chen, X. N., \& Chen, W. P. (2011). An overview of reclaimed water reuse in China. Journal of Environmental Sciences, 23, 1585-1593. http://dx.doi.org/10.1016/S1001-0742(10)60627-4

Zalesny Jill, A., Ronald, S., Zalesny, Jr., Wiese, A. H., Bart Sexton, C., \& Hall, R. B. (2007). Sodium and chloride accumulation in leaf, woody, and root tissue of Populus after irrigation with landfill leachate. Environmental Pollution, 1-9.

\section{Copyrights}

Copyright for this article is retained by the author(s), with first publication rights granted to the journal.

This is an open-access article distributed under the terms and conditions of the Creative Commons Attribution license (http://creativecommons.org/licenses/by/3.0/). 